\title{
Sport w grafice polskich artystek w dwudziestoleciu międzywojennym
}

99

dmiana najnowszą kobiety - człowieka jest sportsmenka. Tę ensoba, wieczny hazad z losem o zycie, najczesciej zas oklaski thú, gdy przepłynie Kanał La Manche, zdobędzie nagrodę olimpijską za rzut dyskiem lub weźmie rekord w skoku na nartach, gdy przeleci Atlantyk!"1. Wypowiedź ta, choć podszyta ironia, jest znakiem czasu - obrazuje przemiany, które zaszły w odrodzonej II RP nie tylko na gruncie polityczno-prawnym, ale także w sferze mentalno-obyczajowej stopniowo „oswajającej” aktywne uczestnictwo kobiet w nowych domenach życia publicznego. Taki obraz kobiety nowoczesnej - zuchwałej, podejmującej wyzwania w dziedzinach zarezerwowanych do tej pory dla mężczyzn - promowany był w prasie kobiecej od końca lat 20. XX wieku. W „Bluszczu”, „Kobiecie Współczesnej”, „Pracy Obywatelskiej” i czasopismach sportowych („Stadion”, „Start”) pojawiło się wiele artykułów o różnorodnych pasjach nowoczesnych Polek i ich osiagnięciach, także w dziedzinie sportu², choć jeszcze przed 1925 rokiem „kwestia organizacyjna sportu kobiecego nie istniała. Były nieliczne gru-

1 H. Kłosińska, Cżym enturjażmuje sie kobieta?, „Bluszcz” 1930, nr 40, s. 8.

2 Polki uprawiały większość dyscyplin sportowych, także tych uważanych za typowo męskie. Uczestniczyły m.in. w rajdach samochodowych, konkurencjach hippicznych, pilotowały awionetki, uprawiały wioślarstwo. Zob. K. Muszałówna, Sport kobiecy w Polsce, [w:] Almanach spraw kobiecych. Informacje, postulaty, zagadnienia, Warszawa 1933, s. 198. Zob. także M. i J. Lozińscy, Automobiliśsi, lotnicy i inni, [w:] W przedwojennej Polsce. Życie codzienne i niecodzienne, Warszawa 2012. 
py pań, uprawiające różne gałęzie sportu w męskich klubach sportowych. Istniało zaledwie parę na całą Polskę samodzielnych klubów kobiecych"3. Sytuacja ta uległa zasadniczej zmianie w latach 30.; polskie zawodniczki zaczęły odnosić sukcesy przede wszystkim w lekkoatletyce, wioślarstwie i tenisie. Nie tylko sukcesy sportowe, ale też zmiana stylu życia, rosnąca świadomość dobroczynnego działania ruchu, wreszcie moda na określone dyscypliny sportu wpłynęły na popularność tego tematu w różnych dziedzinach sztuki. Dodatkową motywacją do podjęcia tematyki sportowej mogły być konkursy olimpijskie 4 na dzieło sztuki o tematyce sportowej.

W grafice artystycznej dwudziestolecia międzywojennego sport był jednym z najchętniej podejmowanych tematów z obszaru nowej ikonografii. Motywy sportowe atrakcyjne były i dla artystów, i dla artystek. Część z nich sięgała do klasycznych wzorców, uwydatniając harmonię proporcji ludzkiego ciała w zastygłej pozie łucznika czy biegacza tuż przed startem, część kładła nacisk na oddanie gibkości i gry mięśni w wybranej sekwencji ruchu typowej dla danej dyscypliny. Joanna Sosnowska postawiła tezę, że na wystawach sztuki w tematach sportowych lepiej wypadały artystki: „Najwyraźniej czuły się swobodniejsze niż ich koledzy, którzy - jak zauważyła prasa - próbowali nagiąć do tematu swoje wypracowane już na innym polu sposoby przedstawiania. [...] podchodziły one do problemu $\mathrm{z}$ większą swoboda, sięgały po motywy mniej oklepane, a więc nie wyścigi konne, ale piłka nożna lub boks" ". To samo zjawisko, scharakteryzowane przez badaczkę na przykładzie obrazów i rzeźb tworzonych przez artystki w latach 20. i 30, znajduje odzwierciedlenie w grafice artystycznej uprawianej przez kobiety. To właśnie graficzki częściej podejmowały wątki sportowe, a dyscypliny, dla których szukały wyrazu artystycznego (szermierka, tenis, hokej,

3 K. Muszałówna, op. cit., s. 195.

4 O olimpijskich i poprzedzających je Krajowych Olimpijskich Konkursach Sztuki zob.: W. Królak, Olimpijskie konkursy sætuki, [w:] Olimpizm, polski ruch olimpijski i ich materialne swiadectwa w zbiorach Muzeum Sportu i Turystyki, Warszawa 1992; K. Nowakowska-Sito, Od Paryża do Berlina. Artyśsi polscy na Olimpijskich Konkursach Sztuki 1924-1939, [w:] Wyprawa w dwudziestolecie, katalog wystawy, red. naukowa K. Nowakowska-Sito, Warszawa 2008; J. Gola, Sport w sztuce, [w:] Sztuka wsždzie. Akademia Sztuk. Pieknych w Warszawie 1904-1944, katalog wystawy, red. nauk. J. Gola, M. Sitkowska, A. Szewczyk, Warszawa 2012, s. 418. -139 .

5 J. Sosnowska, Poza kanonem. Sztuka polskich artystek 1880-1939, Warszawa 2003, s. 138- 
sporty wodne i sporty zimowe), rzadko były brane pod uwage w malarstwie czy rzeźbie.

Tematykę sportową podejmowały przede wszystkim graficzki warszawskie. Nowatorskie w zakresie tematyki i kompozycji są drzeworyty uczennic Skoczylasa, członkiń Rytu: Janiny Konarskiej, Wiktorii Goryńskiej i Marii Rużyckiej-Gabryel. Dwie ostatnie były pasjonatkami sportu - Wiktoria Goryńska uprawiała wyczynowo szermierkę ${ }^{6}$, rekreacyjnie narciarstwo i pływanie, a Maria Rużycka-Gabryel sporty wodne (zdobyła patent żeglarski) i narciarstwo. Goryńska, autorka kilkunastu unikatowych w sztuce dwudziestolecia drzeworytów przedstawiających ćwiczenia i zawody szermiercze oraz portrety szermierzy, propagowała także wiedzę o tej elitarnej dyscyplinie sportowej ${ }^{7}$. Sporty uprawiane przez Marię Rużycką-Gabryel, jej zamiłowanie do gór i żywiołu wody znalazły odzwierciedlenie w kilkunastu drzeworytach (m.in. W schronisku, Wiosna narciarzy, Smarowanie nart, Sporty wodne).

Janina Konarska, autorka barwnych drzeworytów Piłka nożna / Stadion $^{8}$ (1932), Tenis (1930), Regaty / Wioślarstwo (1928) oraz kilku drzeworytów japonizujących ${ }^{9}$ z przedstawieniem narciarzy: Skoki narciarskie / Zjazd (1929), Narciarze (1929), Narty (1931), nie uprawiała wszystkich tych dyscy-

6 Jako zawodniczka reprezentowała klub Warszawianka; w 1934 r. została włączona do polskiej reprezentacji na Mistrzostwa Europy w Szermierce. W 1937 r. zdobyła III miejsce w Turnieju Floretowym Pań o Puchar Wędrowny. Artystka weszła także w skład zarządu Polskiego Związku Szermierczego (w latach 1934-1936 prowadziła utworzony przy nim referat Spraw Kobiecych). Ukończywszy kurs sędziowski w 1938 r. została jedną z trzech pierwszych polskich sędzin szermierki. O tym obszarze aktywności Goryńskiej pisała A. Wagner, Wiktoria Goryńska - graficzka i florecistka z lat 30., „Kultura Fizyczna” 2003, nr 5-6, s. 22-25.

7 W. Goryńska, Sz̧ermierka, [w:] Szermierka, tucznictwo, strzelanie, pod red. K. Muszałówny, E. Reicherówny, t. 4, Warszawa 1935. Rozdział ten artystka wzbogaciła poglądowymi rysunkami ilustrującymi sylwetki szermierzy w różnych fazach pojedynku, sposób trzymania szpady i floretu, błędy postawy. Podobne rysunki Goryńskiej znalazły się w artykułach o tej dyscyplinie sportowej (S. Goryńska, Florecistki w Warszamie, „Praca Obywatelska” 1934, nr 14, s. 14-15; L. Ciechanowiecka, Lek na sadyzm $i . .$. reumatyzm, „ABC literacko-artystyczne" 1934, nr 13, s. 2).

8 Za tę pracę Janina Konarska w Olimpijskim Konkursie Sztuki i Literatury w 1932 r. w Los Angeles otrzymała srebrny medal.

9 Mieczysław Sterling docenił to twórcze przetworzenie drzeworytu japońskiego: „Fascynująca subtelność w dostosowaniu koloru i sposobu widzenia japońskiego drzeworytu 
plin, ale jeździła na nartach i obserwowała narciarzy na stoku. Charakterystyczny dla tej artystki sposób podejścia do tematu i ujęcia sylwet ludzkich przejawiał się w tym, że wybierała sporty zespołowe lub zjazdy narciarskie uzasadniające równoczesne przedstawienie wielu postaci. W wymienionych wyżej pracach sylwety sportowców sprowadzone zostały do kaligraficznych „pajęczych” - jak to określiła krytyk Nela Samotyhowa ${ }^{10}$ - znaków. W drzeworytach Pitka nożna, Tenis i Regaty Konarska ukazała stadion, kort i tor regatowy z lotu ptaka. Wspólne cechy tych kompozycji pokreśliła Irena Jakimowicz ${ }^{11}$ : widok $z$ góry, intensywne barwy, kolor traktowany niemal po malarsku, kładziony płaska plamą i na ogół brak czarnego konturu właściwego drzeworytowi. Na ten ostatni wyróżnik drzeworytów artystki zwróciła także uwagę Anna Manicka: „metoda Konarskiej przypomina wykonywanie kolażu z kilku elementów - konstruowanie kompozycji z kilku współistniejących różnobarwnych plam (współgrających z miejscami niezadrukowanymi)"12. Obserwacje zjawisk atmosferycznych i światła na ośnieżonych stokach górskich Konarska przełożyła na subtelne, precyzyjnie cięte formy. Artystka podpatrzyła i oddała przecinające się ślady nart i odciski kijków na śniegu, tworząc dekoracyjny, delikatny deseń współgrający z gęstą „siatką" cieni rzucanych przez gałęzie drzew. W kompozycjach tych dokonała także syntezy - uogólniła sylwety, zgrupowała motywy, by osiągnąc harmonię bez natłoku elementów. Dla Konarskiej sporty, zwłaszcza te uprawiane na łonie natury, były także impulsem do ukazania walorów przyrody i kreowania nastroju. W drzeworytach o tematyce narciarskiej (ale i w Regatach) artystka nie zaniedbała dużych płaszczyzn pokrytych śniegiem gór i nurtu rzeki. Odpowiednie draśnięcia klocka drzeworytniczego na całej po-

do własnej psychiki mają barwne drzeworyty Konarskiej” (M. Sterling, Plastyka, „Wiadomości Literackie" 1930, nr 14, s. 4).

${ }^{10}$ „Z tych obserwacji, bystrych i trafnych, z wżycia się w ton nowoczesnego świata, powstaja pełne wykwintu karty drzeworytów, poświęconych sportowi. Płyną w nich, suna, pędza, skaczą zwinni i pełni lekkości ludzie o sylwetkach owadzio - czy pajęczo - delikatnych” (N. Samotyhowa, Wspótczesne Grafičkei Polskie, cz. II, „Kobieta Współczesna” 1933, nr 17, s. 332).

11 I. Jakimowicz, Pieć wiekón grafiki polskiej, katalog wystawy, Warszawa 1997, s. 156.

12 A. Manicka, Drzeworyt barwny w dwudziestoleciu - epigoni i nowatoray, [w:] Wielość w jedności. Drzeworyt polski po 1900 roku. Materiały z sesji naukowej 23 X 2009 roku, red. M. Woźniak, B. Chojnacka, Bydgoszcz 2011, s. 43. 
wierzchni, tworzenie przecinających się zespołów linii, swobodnych fal i jodełek oddających ślady nart decydują o lekkości i subtelności kompozycji. Postacie sprowadzone do niewielkich, schematycznych i w niewielkim stopniu zindywidualizowanych sylwetek są raczej pretekstem do dekoracyjnych rozwiązań (zróżnicowane układy kończyn, nart i kijków narciarskich tworzących plątaninę przecinających się pod różnymi kątami linii) - w przypadku Regat elementem wzmagającym dekoracyjny charakter pracy jest „tłum” parasolek nad głowami kibiców. Część „narciarskich” kompozycji Konarskiej opiera się na grze linii prostych (sylwety) i falistych (ślady nart na śniegu). Pewną narracyjność wprowadza artystka do drzeworytu barwnego Skoki narciarskie / Zjazd (1929), gdzie zawodnikowi towarzyszą kibice tworzacy grupki po obu stronach zjazdu oraz górale z końmi w kraciastych derkach (nie bez znaczenia dla dekoracyjności kompozycji). Regaty ${ }^{13}$ Konarskiej (1929) w zróżnicowanych odbitkach zachowanych w zbiorach muzealnych i prywatnych odzwierciedlająca wachlarz możliwości, jakie można uzyskać z tej samej matrycy. Nasuwa się pewna zbieżność w sposobie zastosowania barwy w drzeworytach Konarskiej i linorytach wykonywanych metoda Claude’a Flighta, nauczana przez niego samego w londyńskiej Grosvenor School of Modern Art od 1925 roku. Grafików z tego środowiska ${ }^{14}$, inspirujących się futuryzmem i wortycyzmem, fascynowała szybkość, dynamika rozwoju transportu, komunikacji, rytm życia w wielkim mieście oraz tematyka sportowa, odgrywająca niebagatelną rolę w ich twórczości linorytniczej. Jednak nie sam fakt podejmowania podobnych wątków sportowych lub ich ujęcia (bo tu są znaczące różnice), ale świetlistość i czystość barw, którą uzyskiwała Konarska, porównywalna jest z wieloma linorytami barwnymi Cyrila Powera (m.in. Ósemka z ok. 1930 roku przedstawiajacą osadę wioślarką, Hokej z 1931), Sybill Andrews (Wyścig w deszrzu, 1930;

13 Odbitka z Muzeum Narodowego w Krakowie (bez odbitych drzew) datowana na 1928 rok, utrzymana w stonowanej gamie barwnej; tę z British Museum, datowaną na 1929 rok, cechują nasycone kolory z turkusową tonią wody i drzewami na linii horyzontu.

14 Zob. M. Parkin, Claude Flight and the Linocut, "Journal of Decorative and Propaganda Arts" vol. 6, Autumn, 1987, s. 26-33 oraz British Prints from the Machine Age. Rhythms of Modern Life 1914-1939, teksty: S. Coppel, S. Rippner, T. E. Rassieur, S. Lussier, R. Mustalish, publikacja towarzyszacca wystawie Rhythms of Modern Life: British Prints, 1914-1939, Museum of Fine Arts, Boston, Metropolitan Museum of Art 2008, London 2008. 
Parasolki), Ethel Spowers (Mokre popoludnie, 1929) czy Lill Tschudi (Rajd w Sawajcarii, 1930).

Drzeworyty barwne Konarskiej sa przesycone światłem, lekkie, pogodne „[...] jakże bowiem traktować sporty, jeżeli nie od strony urody życia, a więc piękna formy i pogody nastroju. Właśnie w ten sposób ujęła Konarska swe Regaty, Tenis, Skocznie, Narciaryy i Jasny Brzeg [...] Sport - to ruch i powietrze - Konarska umiała wyrazić je mowa sztuki, bez futurystycznej ekstrawagancji i ponad reprodukcją naturalizmu, przez deformację perspektywiczną i irracjonalność wrodzonego talentu, dzięki czemu świadomość zamierzeń nie przeistoczyła się w nudę i jałowa pedanterię mędrkowania [...] Konarska pokazała w swych barworytach, że umie znaleźć w temacie jego sens własny, pokazać go z cała sugestywnościa artystyczną, potrafiąc przy tym na reminiscencjach dawności zbudować dzieło najzupełniej nowoczesne" ${ }^{\text {"15. }}$

Wanda Telakowska, tak jak Konarska, była drzeworytniczką wybitnie wyczuloną na czystość koloru i harmonijne zestawienia barwne. Obie wykonywały po kilka wersji kolorystycznych tej samej kompozycji, by dzięki zmianie gamy barwnej uzyskać zupełnie inny nastrój, zbadać możliwości zasugerowania odmiennych warunków atmosferycznych, jak np. Konarska w pracy Narciarze (w czasie słonecznej aury i tuż przed załamaniem pogody, kiedy słońce przed ulewą czy śnieżyca jeszcze prześwieca przez burzowe chmury). Podobnie Wanda Telakowska kompozycję Sport i prayroda (1932) wykonała w różnych wariantach: jedną w ugrach i czerni, inną w brązach i szarości, osiagając odmienny nastrój. Ulubionym motywem tej artystki były żaglówki z rozpostartymi, wydętymi przez wiatr trójkątami żagli i kajaki na tle malowniczych nadbrzeży oraz portowych miasteczek (Regaty / Przystań, 1935; Żaglówki, 1934; Biwak; W małej zatoczce, 1934). Szczególny nacisk kładła na harmonijne współgranie trzech elementów: wody, roślinności i architektury. Człowiek, którego sylweta jest uproszczona lub sprowadzona do jednobarwnego znaku, odgrywa tu niewielką rolę. Koncepcja Telakowskiej nie opierała się na określaniu specyfiki dyscyplin wodnych, lecz raczej ukazaniu piękna idei sportu; żaglówki czy kajaki były raczej pretekstem do

\footnotetext{
15 T. Cieślewski syn, Barworyty Janiny Konarskiej, „Wiadomości Literackie” 1930, nr 20,
} s. 3. 
atrakcyjnego ujęcia pejzażowego z rzeką w roli głównej, malowniczą zatoczka, portem i widokiem na wspaniałą architekturę miast i miasteczek ${ }^{16}$.

Umiejętne działanie barwą w pracach o tematyce sportowej niewatpliwie podnosiło ich walory estetyczne, barwy energetyzowały przekaz, umiejętnie rozłożone wzmagały dynamikę sylwet w ruchu. Ale nie mniej interesujące sa prace utrzymane w czerni i bieli. Ta estetyka najbliższa była Wiktorii Goryńskiej, choć w jej dorobku są także drzeworyty barwne i odbitki kolorowane akwarela. Najlepsze ,sportowe” drzeworyty tej artystki są odzwierciedleniem jej wielkiej pasji. Ćwiczqcy szermierze (wśród których jest wyróżniona kobieta z charakterystyczną bujną fryzurą przycięta na wysokości uszu wskazująca iż jest to Goryńska) to z kolei świetne studium dziewięciu dynamicznych sylwetek w zróżnicowanych pozach ujętych na kilku planach ${ }^{17}$. Ta scena, zapewne jedna $z$ wielu, w jakich uczestniczyła lub miała możność obserwować Goryńska w trakcie ćwiczeń, pozwala zajrzeć za kulisy oficjalnych zawodów. Uchwyceni jak w kadrze fotografa w czasie różnych zajęć szermierze rozciągaja ciało, rozgrywaja pojedynek, rozmawiaja. Podobna koncepcja znalazła odzwierciedlenie w wielofiguralnej kompozycji Szermierze. W drzeworycie Florecistki wegierskie (1934) ${ }^{18}$ Goryńska pokazała posagowe kobiety w białych strojach do ćwiczeń, wykonujace uroczyste, niemal rytualne gesty. Sportsmenka stojąca wkłada rękawice, jej floret opuszczony w dół podtrzymywany jest w zgięciu łokcia ${ }^{19}$; florecistka przyklękająca, by odłożyć maskę, ujęta jest w pozie niemal tanecznej, z rozpiętymi po diagonalu ramionami. Gracja i elegancja ruchów ${ }^{20}$, które cechuja

16 Nawet w pracach nienawiązujacych w wyraźny sposób do sportu (Motyw z Jugosławii, drzeworyt, 1935) Telakowska na tle architektury umieszczała żaglówki.

17 Podobne ujęcie artystka zastosowała w drzeworytach Florecistki wegierskie (1934) i Szermierze (ok. 1932-1935 r.). O pracach tych pisała m.in. M. Sitkowska, Wiktoria Goryńska 1902-1945. Katalog grafiki, Muzeum Narodowe, Warszawa 1977.

18 Znane są dwie różne ryciny z tego samego roku pt. Florecistki wegierskie; jedna z nich to rycina z konturowym zaledwie zarysem pojedynkujących się postaci (zb. Biblioteki Uniwersytetu Warszawskiego), druga, ze zbiorów Muzeum Narodowego w Warszawie, to kompozycja omówiona powyżej.

${ }_{19}$ Z postaci tej bije patos, z jakim ukazała Goryńska Joannę d’Arc w cyklu drzeworytów pod tym samym tytułem z 1927 roku.

20 W przytoczonym wyżej „,podręczniku” szermierki artystka pisała: „Szermierka pań, prowadzona na właściwym poziomie, ma wiele pokrewieństwa z klasycznym baletem: tak 
tę dyscyplinę, zostały tu świetnie uchwycone. W tle rozgrywa się pojedynek na florety kobiet, któremu przypatrują się sędziowie i inne zawodniczki ${ }^{21}$. W Szermierce z 1934 roku motyw walki autorka wzbogaciła wattkiem rodzajowym - dwie kobiety (jedna $z$ nich to zapewne sama artystka) spoglądaja z góry, z balkonu na planszę szermiercza, gdzie odbywa się pojedynek - widz przyjmuje ich punkt oglądu. W oświetlonej centralnej części wąskiego prostokąta maty jawią się dynamiczne, ale też dekoracyjne w swych pozach postacie florecistów. W tle, niedaleko maty, przygląda się zawodom para kibiców z psem. Znane są także drzeworytnicze portrety szermierzy autorstwa Goryńskiej (Szermierz - portret majora Szombathely z ok. 1931 roku, Szermierz z 1931 roku i Szermierz z 1934 roku) to statyczne, pełne patosu postacie będące ucieleśnieniem rycerskich reminiscencji spotkań szpadowych. O powołaniu i zamiłowaniu Goryńskiej do tej dyscypliny, świadczy drzeworyt Florecistke - autoportret (ok. 1932-1935). Jak artystka zaprezentowała siebie światu? W jakim kolejnym już wcieleniu (z kilku autoportretów jakie znamy) jawi się w tej pracy? Przedstawiła siebie na pierwszym planie, na tle ćwiczących kolegów, jako ciemną sylwetę ukazaną na tle jasnego parawanu. Profilowe ujęcie uwydatnia bujną, krótko podciętą fryzurę cieniowana powyżej linii karku i linię orlego nosa. Z floretem wzniesionym w prawej dłoni i z maską pod pachą, Goryńska powiela swój wizerunek jako nowoczesnej, energicznej, pewnej siebie kobiety. Pchnięcie floretem, jak i cięcie deski drzeworytniczej, wymagało decyzji, wykonania nieodwołalnego ruchu i takiej samej precyzji. Żadna polska graficzka nie połączyła tak odległych wydawałoby się dziedzin i to z takim znakomitym rezultatem. O ile prasa dostarczała informacji o sportowych wynikach Goryńskiej, to o kunszcie szermierczym artystki można wnioskować tylko na podstawie jej opublikowanych wypowiedzi na temat reguł i piękna tej dyscypliny.

samo siła zawsze powinna być niewidoczna, przejawiając się tylko w formie sprężystości i zwinności ruchów (...)” W. Goryńska, Szzermierka, op. cit., s. 3-4.

21 Takie ujęcie zawodniczek węgierskich może być wyrazem uznania dla ich osiagnięć na macie - w ówczesnej Europie była to najlepsza drużyna, trenowana przez Adalberta de Szombathely i jego żonę, którzy czasowo przebywali w Polsce, szkoląc także polskie florecistki. 
Ale prace, jakie pozostawiła 22 , i część zachowanych klocków drzeworytniczych $^{23}$ świadczą o jej niezwykłym kunszcie graficznym.

Niemal wyłącznie w czerni i bieli tworzyła także Maria Rużycka-Gabryel. Drzeworyt zaczęła uprawiać dopiero w 1932 roku po wcześniejszych próbach z akwaforta. Tadeusz Cieślewski - syn, kolega artystki z grupy Ryt, zwolennik rasowości ${ }^{24}$ drzeworytu w jednej z recenzji pisał: „Swada niefrasobliwej prostoty wyżłabiania powierzchni klocków przez Rużycką ujmuje rześkością niemal sportowa [...] Plama czy kreska graficzna sama przez się zdaje się dla Rużyckiej być mniej ważna, niż efekt całości jako kompozycji zrównoważonej z punktu widzenia czarności i bieli. Dzięki temu daremne byłoby się doszukiwać w jej rycinach rozwiązywania zagadnień graficznych"25. Jednak ganione w recenzji bardzo swobodne cięcie klocka w kompozycjach sportowych oddawało dynamikę narciarstwa, któremu artystka poświęciła wiele prac. Rużycka była jedną z nielicznych „Rytowniczek”, dla której powodem powstania kompozycji nie była chęć rozwiązywania wyłącznie zagadnień graficznych. Mogło to wynikać z pierwszego, malarskiego wykształcenia artystki w krakowskiej ASP. Skoczylas, pod kierunkiem którego kształciła się już w Warszawie w zakresie drzeworytu, nie wpłynął zasadniczo na sposób widzenia świata ukształtowanej już poniekąd artystki, która choć odniosła sukcesy ${ }^{26}$, proponowała odmienną koncepcję drzeworytu od grafików wykształconych w warszawskiej ASP. Artystka po latach pisała: „[...] Jeżeli ktoś w grafice wywarł na mnie wpływ, to chyba tylko Wojnarski, mój pierwszy mistrz i to raczej w dziedzinie techniki. Ze Skoczylasem miałam b. mało styczności, choć pracowałam w jego klasie. Sko-

22 W zbiorach MNW, BN, BUW, BJ, Ossolineum.

23 Zachowal się w zbiorach prywatnych klocek drzeworytniczy z kompozycją $W$ plywalni (przed 1931), w której artystka ukazuje fragment sali gimnastycznej i basenu, gdzie odbywają się treningi.

24 Zob. T. Cieślewski syn, Dræeworyt w kesiqż̧ce, tece i na ścianie: unvagi polemične o graficznej rasowości drzeworytu, Warszawa 1936.

25 T. Cieślewski syn, Siedem artystek na mystawie Rytu, „Pani Domu” 1936, nr 2, s. 25-26.

${ }_{26}$ W 1933 roku brała udział w I Międzynarodowej Wystawie Drzeworytu zorganizowanej w Instytucie Propagandy i Sztuki w Warszawie. W 1936 reprezentowała Polskę na XI Olimpiadzie Sztuki w Berlinie. 
czylas zostawiał mi zupełną swobodę, odnosząc się zresztą b. życzliwie, a ja czułam się już wtedy raczej samodzielna w grafice"27.

Sporty zimowe, która sama uprawiała, przedstawiała Rużycka w reportażowy sposób, inaczej niż większość artystek. Kadrowanie bliskie ujęciom fotograficznym, czasem świadomie ,ucięty" fragment motywu - to była świeża koncepcja na gruncie Rytu. Stricte sportowy aspekt narciarstwa reprezentowany jest nielicznymi pracami (Christiania. Narciary, 1938), za to bogaty jest wątek rodzajowy - w dorobku Rużyckiej więcej jest prac ukazujących zajęcia i czas wolny narciarzy: Smarowanie nart (1933), Wiosna narciarzy (1935), Odpoczynek narciarzy (1936). Sporty wodne - różne dyscypliny (1937) to z kolei drzeworyt, w którym artystka wypowiada się poprzez biały ślad narzędzia, redukując czerń do niezbędnego minimum rozpoznawalności sylwet i obiektów. Ukazuje symultanicznie kilka rodzajów sportów ${ }^{28}$ wodnych i formy spędzania czasu nad woda: obok zawodów pływackich, żeglarstwa, wioślarstwa (pomosty, przystanie) są też idylliczne ujęcia ludzi wypoczywających nad wodą (piknik), pływających łódkami. Wszystko, co przyjemne, Rużyckiej kojarzy się z woda - nie pomija nawet przepływającego stadka kaczek. W kompozycji dominuje żywioł wody, ale czerń drobnych elementów (ludzkich sylwet, łodzi, wysepek z drzewami i niewielkich zabudowań), równomiernie wypełniając płaszczyznę, równoważy „powódź” bieli.

Wyłącznie w technikach metalowych wypowiadały się artystki warszawskie należące do grupy Fresk. Niezwiązane z ASP i pracownią Skoczylasa, były uczennicami szkoły Blanki Mercère, a w tajniki grafiki wprowadzała je nestorka warszawskiej akwaforty, Zofia Stankiewicz. Kwintesencja stylu art déco sa prace Zofii Sznuk-Koskowskiej z motywami sportowymi. Graficzka wykonała kilka akwatint o tej tematyce, jednak jej ujęcie znacznie

27 List do I. Rylskiej z 1 V 1961, rkps, k. 75. Materiały Ireny Rylskiej, dot. lwowskiego środowiska artystów grafików w latach dwudziestolecia międzywojennego, Biblioteka Ossolińskich, sygn. 17185/II.

${ }^{28} \mathrm{Na}$ podobnym pomyśle - symultanicznych, niezależnych od siebie epizodów - opierała się kompozycja „sportowego" drzeworytu Mrożewskiego Dawniej i teraz. (Olimpiada) z 1936 roku, z tym że artysta skontrastował scenki z igrzysk starożytnej Grecji ze współczesnymi dyscyplinami (hokej, boks). Poza równolegle rozgrywającym się scenkami obie prace znacząco różnią się sposobem opracowania matrycy. Mrożewski otrzymał nagrodę (wraz ze Stanisławem Ostoja Chrostowskim) na wystawie Sport w sæztuce w ramach XI Igrzysk Olimpijskich w Berlinie. 
różni się od koncepcji artystek przywołanych wcześniej. Dla Sznuk-Koskowskiej konkretna dyscyplina sportu (większość zimowych) była pretekstem do ukazania eleganckiej sylwety modnie ubranego mężczyzny, ale też dzieci podczas zabawy. Jej Skoczek narciarsk $2^{29}$ (1931), w plakatowym niemal ujęciu, unosi się z rozpostartymi ramionami na tle zsyntetyzowanego krajobrazu: ośnieżonych szczytów górskich ujętych w formy piramid rytmicznie powielających swe formy, jodeł o usztywnionych gałęziach podporządkowanych prawom geometrii. Kompozycji dopełniają kozice górskie o niemal identycznych sylwetkach, skaczące jedna nad drugą w tym samym kierunku co narciarz. Anna Manicka, która jako pierwsza dostrzegła walory tej pracy, tak odmienne na tle warszawskiego drzeworytu międzywojnia, omówiła ją w tekście katalogu wystawy Dialog czarno na białym ${ }^{30}$. W nieco innym kontekście odniosła się do tejże pracy w późniejszym artykule ${ }^{31}$, zwracając uwage na cechy stylistyczne oraz detale ubioru doskonale odzwierciedlające ówczesną modę. Sznuk-Koskowska nie poprzestała na tej pracy, jeśli chodzi o tematykę sportowa. Jej Lyżmiarz z 1933 roku to mężczyzna o bardzo zbliżonych rysach twarzy do narciarza i takim samym typie uczesania. Zapatrzony w dal kreśli łyżwami na powierzchni lodowiska koła piruetów. Zwraca uwage elegancja jego ruchów i powiewający szal (tak samo u Skoczka), sugerujący pęd, jak i rozłożone ręce, dzięki którym utrzymuje równowagę. Z kolei akwatinta z akwaforta Śliggawka (przed 1938 r.), zdradzająca pewne problemy artystki już na etapie rysunku (sylwety dzieci), również wpisuje się w styl art déco. W najsłabszej chyba ze swoich prac graficzka przedstawia grupe sylwet dzieci na łyżwach w bardzo zróżnicowanych pozach - ukazuje próbę jazdy figurowej na lodzie, łapania równowagi i upadki, a w tle dzieci zjeżdżaja na sankach. Ta scenka w planie

29 Akwatinta z akwaforta, zbiory Muzeum Narodowego w Warszawie.

30 Dialog czarno na biatym. Grafika polska i wegierska 1918-1939, katalog wystawy Muzeum Narodowe w Warszawie - Magyar Nemzeti Galéria w Budapeszcie, teksty: A. Manicka, K. Bakos, Warszawa-Budapeszt 2009, s. 137-138, repr. s. 128. Reprodukcja tej pracy zapowiadała także warszawską wystawę w formie plakatu.

31 A. Manicka, Akwatinta i temat kobiecy. Artystki graficzki uprawiajace akwatinte w dwudziestoleciu międzynojennym, [w:] Wielość w jedności. Techniki wklestodruku w Polsce po 1900 roku. Materiały z sesji naukowej 18-19 października 2012, red. naukowa B. Chojnacka, M. F. Woźniak, Muzeum Okręgowe im. L. Wyczółkowskiego w Bydgoszczy, Bydgoszcz 2013, s. 147. 
drugim przedstawiona jest jakby z pozycji upadającego, który „fika kozła”. Kompozycja z linia pagórka i drzewami po diagonalu jest ciekawą koncepcją wzmagająca jeszcze dynamikę pierwszego planu.

Tenis (lata 30.) w ulubionej technice Koskowskiej, akwatincie z akwafortą, jest jedną z ciekawszych kompozycji rozegraną na opozycji dwóch graczy usytuowanych blisko siebie, po przeciwnych polach siatki. Wzrok widza prowadza rozmieszczone po diagonalu linie kortu. Sylwety obu mężczyzn (odzianych w białe spodnie, koszulę / pulower z wycięciem w szpic i obuwie zgodnie z ówczesnym trendami) również formowane są po ukosie postacie na ugiętych nogach odchylają się od osi w przeciwne strony, jakby w tanecznych pozach. Gdyby nie konkretne określenie miejsca jako kortu, trzymane w dłoniach mężczyzn rakiety i piłeczka w polu, ten układ byłby wiarygodny jako choreograficzny. Koskowska, preferująca tego typu ujęcia, kreuje „swój” typ mężczyzny, dba o wszelkie detale stroju, fryzury, mimikę i gesty. Typ sportowy był jednym z najbardziej pociagających wcieleń nowoczesnego mężczyzny - młodego, gibkiego, poruszającego się z gracją i doskonale ubranego. Być może pierwowzorem tej postaci był ukochany artystki, może w pracach tych wykreowała swój niedościgniony ideał ze sfery marzeń, a może inspirowała się wytworem rodzimej kinematografii ${ }^{32}$.

Tenis jest tematem akwaforty z akwatintą (1936) Marii Wolskiej-Berezowskiej. Większość prac tej artystki (także uczennicy Blanki Mercère i Zofii Stankiewicz) utrzymanych w stylu art déco inspirowana była folklorem i literatura. Tenis i Kajak, dwa przedstawienia odbiegające tematycznie od głównego nurtu jej zainteresowań, których tytuły sugeruja sportowy temat, nie odnoszą się właściwie do sportu, odzwierciedlając przede wszystkim walory przyrody. Tenis to w większym stopniu pochwała rekreacji na świeżym powietrzu niż studium postaci w ruchu. Kort ogrodzony siatka ukazany jest $z$ dala, na tle pagórka $z$ wysokimi drzewami, a sylwetki są niewielkie, potraktowane umownie. Taka sama idea przyświecała zapewne arty-

32 Również w polskim filmie pojawił się wątek tej dyscypliny sportowej w filmie Jadz̨ia z 1936 roku w reżyserii Mieczysława Krawicza. Przystojnym, świetnie ubranym i wysportowanym amantem jest tu Jan Oksza, syn właścicielki największego w Warszawie sklepu sportowego, który ma oczarować i przekonać mistrzynię tenisa, Jadzię Jędruszewska, aby zechciała grać rakietami jego firmy. 
stce przy tworzeniu akwatinty Kajak $k^{33}$ (przed 1938 rokiem). Przejęty przez nia, a charakterystyczny dla drzeworytniczek Rytu widok z oddali, z lotu ptaka, obejmuje zalesione pagórki i kajak z żaglem, w którym widoczne sa ludzkie sylwetki. Obłoki na niebie dopełniaja ten sielankowy krajobraz, gdzie człowiek stanowiacy element natury korzysta z jej dobrodziejstw.

Gra w piłkę - nie tylko jako określona dyscyplina sportowa, ale aktywność ruchowa i rozrywka dostępna dla każdego niezależnie od wieku i umiejętności - była szczególnie popularnym tematem, podejmowanym przez twórców obu płci zarówno w malarstwie, rzeźbie, jak i grafice. Kobiety grające w siatkówkę (Gra w pitke, lata 30.) to temat drzeworytu Janiny Róży Giedroyć-Wawrzynowicz ${ }^{34}$. Amatorki sportu ujęte na pierwszym planie na tle siatki, odziane w wygodne stroje (krótkie spodenki na szelkach, koszulki z krótkimi rękawami), wyciagają w górę ręce ku niewidocznej piłce. Pozy tych kobiet sa jednak wystudiowane, ruchy pełne gracji, dłonie ułożone w geście bardziej tanecznym niż pozwalającym na przyjęcie piłki. To nowoczesne Gracje, którym obcy jest ferwor walki o piłkę, o wygraną $a^{35}$. Ich wdzięcznie upozowane sylwety zbliżone są do rozwiązań artystów grupy Rytm; pod tym względem Gra w pitkę różni się od innych drzeworytów Wawrzynowicz, która podejmowała wiele tematów bliskich codziennemu życiu, pracy kobiet, scen rodzajowych w bardziej realistycznym ujęciu. Nie jest to jedyny drzeworyt Janiny Giedroyć-Wawrzynowicz o tematyce sportowej; kolejny ukazuje zawodnika skaczącego przez przeszkodę, jesz-

33 Praca w zb. Biblioteki Narodowej.

34 Janina Róża Giedroyć-Wawrzynowicz, uczennica Skoczylasa, w swej twórczości drzeworytniczej odeszła daleko od wizji sztuki narodowej Skoczylasa i od tzw. rasowego drzeworytu propagowanego przez Tadeusza Cieślewskiego syna. Od 1932 roku stosowała w swych drzeworytach technikę białego druku na czarnym papierze. Pisała o tym „wynalazku”: „[...] zrobiłam dzisiaj linoryt tą moją «rewolucyjną techniką» i już mam próbną odbitkę, z której jestem zadowolona. Wyszły takie miękkie i swawolne linie" (List do przyjaciółki z 1933 r. Cyt. za: R. Wawrzynowicz-Bilip, O mojej mamie, [w:] Wydobyć z rapomnienia, katalog wystawy, red. J. Bochiński, J. Plapis, Muzeum Historyczne M. St. Warszawy, Warszawa [2008], s. 11).

35 Inna warszawska graficzka, Irena Dybowska-Jasińska zobrazowała w akwaforcie z akwatintą Gra w piłke / Rugby z 1931 roku walkę mężczyzn o piłkę. Ruch graczy jest tu o wiele bardziej naturalny i dynamiczny niż w pracy Wawrzynowicz. Gracze wybijają się w skoku gotowi na przyjęcie piłki o charakterystycznym kształcie, w górę wyciągnięte są ręce z otwartymi dłońmi i rozcapierzonymi palcami kilkunastu postaci. 
cze inny poświęcony jest sprinterkom ${ }^{36}$. W tym ostatnim, w sposobie ujęcia biegaczki na pierwszym planie graficzka nawiązuje do nurtu nowego klasycyzmu. Bohaterka o klasycznej linii czoła i nosa, z falistymi, ufryzowanymi pasmami włosów ma przymknięte migdałowe oczy; głowa wydaje się „graficznym” odpowiednikiem kobiecych głów autorstwa malarzy i rzeźbiarzy Rytmu ${ }^{37}$.

Z innych dyscyplin sportowych, które inspirowały graficzki, można wymienić boks. Litografia Bokser (1934) Natalii Landau to całopostaciowy portret rozgrzewającego się do walki zawodnika, z kolei Izabela Borowska z Wilna wykonała w linorycie Gtowe boksera ujęta jak w kadrze fotograficznym - w dużym zbliżeniu na tle ringu. Zupełnie inna koncepcję zaproponowała lwowska graficzka Maria Opolska w suchorycie z 1939 roku Boksersy na ringu ${ }^{38}$. Ukazując przeciwników na prowizorycznym podeście zbudowanym z desek w niewielkim, bliżej nieokreślonym pomieszczeniu, gdzie zgromadziła się grupa gapiów, sugeruje, że jest to raczej pojedynek amatorski. Graficzka ta wykonała także suchoryt Na stadionie (przed 1939). Jej całą uwagę pochłonęło jednak graficzne rozwiązanie postaci kibiców tłumnie zgromadzonych na trybunach, a nie grupka ledwo widocznych, biegnacych zawodników.

Tematykę sportowa podjęła również Maria Duninówna, graficzka Rytu, najwyraźniej specjalnie na wystawę Sport w štuce; nigdy wcześniej (i później) nie pojawiły się w jej pracach tego typu motywy. Maria Grońska ${ }^{39}$ wymieniła i scharakteryzowała trzy drzeworyty (Rzut dyskiem, Skijöring i Kon w skoku) z siedmiu, które artystka wykonała w 1936 roku (Rqut kula, Skijöring, Bokseray, Zawody bippiczne, Biegacze, Skok o tyczce, Rzut dyskiem / Dyskobol). Były one także prezentowane na wystawie indywidualnej ${ }^{40} \mathrm{w}$ Towarzystwie Zachęty Sztuk Pięknych w tym samym roku. W recenzjach prasowych od-

\footnotetext{
36 Stadion; odbitka w zbiorach Muzeum ASP w Warszawie.

37 Wacława Borowskiego, Eugeniusza Zaka, Henryka Kuny czy Stanisława Szreniawy-Rzeckiego.

38 W zbiorach Muzeum Narodowego we Wrocławiu.

39 M. Grońska, Nowoczesny drzeworyt polski, op. cit., s. 183.

40 Kolekcje prac Marii Dunin, Zygmunta Dunina, Przewodnik po wystawie Towarzystwa Zachęty Sztuk Pięknych, nr 115, Warszawa, Towarzystwo Zachęty Sztuk Pięknych, 1936, s. 19, 21.
} 
notowano ewolucję języka graficznego i odmienne podejście Duninówny (do tej pory operującej kontrastem bieli i czerni płaskich plam), akcentując dynamikę, swobodę i umiejętne działanie światłocieniem w drzeworytach o motywach sportowych ${ }^{41}$.

Graficzki podejmowały tematykę sportową z różnych pobudek; dla tych uprawiających sport nie tylko rekreacyjnie sztuka była naturalną kontynuacja pasji na innym obszarze aktywności. Prace Goryńskiej to znakomite studia postaci w charakterystycznych pozach, ujęcia, w których ważne są niuanse ruchu dłoni, sposób trzymania maski, szpady czy floretu. Jej kompozycje i sposób ukazania postaci potwierdzają doświadczenie i praktykę na planszy szermierczej, ale przede wszystkim są świadectwem doskonałego warsztatu drzeworytniczego, świadomości możliwości tej techniki i „mądrej” dłoni prowadzącej rylec. Dodać należy, że Goryńska władała biegle nie tylko rylcem i floretem, ale i piórem publikując liczne artykuły o polskiej grafice. W przypadku drzeworytów Rużyckiej są to najczęściej impresje, pogodne sceny w ujęciu rodzajowym, pokazujące codzienność ludzi gór i turystów.

Dla wielu graficzek sport, szczególnie dyscypliny pozwalające na obcowanie z przyroda, jak sporty wodne (kajaki, żaglówki) były jedna z form spędzania wolnego czasu. Przyjemność płynąca z przemierzania szlaków wodnych i doświadczania uroków natury znalazła chyba najpełniejsze odzwierciedlenie w drzeworytach barwnych Wandy Telakowskiej. Nowoczesnością i nowatorskim ujęciem uderzają stadion i kort Janiny Konarskiej, w widoku z góry, uwydatnione jako prostokątna i owalna plama o intensywnej barwie. Artystka, która uwolniła się spod wpływów Skoczylasa tak ewidentnych w jej studenckich i wczesnych samodzielnych pracach, w cyklu sportowym stworzyła elegancki, wyrafinowany typ kompozycji barwnej

41 S. Podhorska-Okołów podkreśliła ,rozmach i naturalność ruchu, niekłamaną dynamikę ciała ludzkiego - większą swobodę i szerokość faktury” (S.P.O. [S. Podhorska-Okołów], Zygmunt i Maria Dunin, „Bluszcz” 1936, nr 39, s. 13.) Nela Samotyhowa sprecyzowała charakter tej przemiany w twórczości Duninówny: „Ostatnim wyrazem ciekawej ewolucji tej artystki sa plansze na temat sportu, dynamiczne, świetliste i światłocieniowe, o kreskowaniu subtelnie zagęszczonym, wydobywającym i akcentującym bryłę. Sylwetkowość lat poprzednich została w nich pokonana” (N. Samotyhowa, W'sód dzieł sæ̨tuki, „Praca Obywatelska” 1936, nr 19, s. 11). 
nowego typu. Zauważalne inspiracje drzeworytem japońskim sa już tylko echem „odrobionej” niegdyś lekcji - Konarska pamięta ja, ale proponuje nową koncepcję, wyrażoną własnym, graficznym językiem.

Wobec popularności sportowego motywu w sztukach plastycznych i konkursach ogłaszanych na dzieło o tematyce sportowej głos zabrali krytycy. Bacznie śledząc poziom prac i sposób ujęcia tematu, wypunktowali zarówno niezrozumienie specyfiki przedstawianej dyscypliny sportowej i wynikającą stąd sztuczność ${ }^{42}$ póz i gestów, jak i próby pójścia po linii najmniejszego oporu ${ }^{43} \mathrm{w}$ zakresie doboru motywu. Juliusz Starzyński w ocenie Krajowego Konkursu Olimpijskiego i wystawy pokonkursowej Sport w sztuce (1936) ubolewał nad niedostateczna, powierzchowna zazwyczaj znajomościa przedstawianej dyscypliny, a z drugiej strony przestrzegał przed zbytnia łatwościa dostosowania własnej maniery artystów do tematu, który z dyscyplinami sportu nowoczesnego nie ma nic wspólnego ${ }^{44}$. W tym samym artykule pozytywnie ocenił w dziale grafiki drzeworyty Marii Rużyckiej. Wobec podnoszonych przez krytyka błędów popełnianych często przez arty-

42 K. Winkler, Plastyka. Wystawa Sport w sqtuce w IPS, „Droga” 1931, nr 12, s. 1028.

43 S. Podhorska-Okołów w artykule Sport w sæztuce. Wystawa obrazón sportonych w IPS w Warszamie, („Przegląd Sportowy” 1931, nr 88 z 4 XI, s. 8) pisała: „Większość ułatwiła sobie zadanie, poprzestając na akcesoriach sportowych, takich jak strój, poza, krajobraz, luźne połączenie sprzętu sportowego z postacią ludzką". Wacław Husarski zwrócił uwagę na brak związku ze sportem nowoczesnym akwarel Skoczylasa z lat 1921-1925 (Łucznik stojacy, Św. Hubert, Łucznik kleczacy, Diana na towach) wysłanych na konkurs olimpijski w 1928 roku (W. Husarski, Z wystaw, „Tygodnik Ilustrowany” 1928, nr 16, s. 308).

44, ,...] w naszej wielowarstwowej, przespecjalizowanej kulturze mimo pozorów wspólnoty, żyjemy rozproszkowani na atomy, rozbici na klany fachowców, wzajemnie się sobą nie interesujących. Zarówno sport jak i sztuka stały się domenami «speców», a ich penetracja życiowa jest wciąż jeszcze bardzo niedostateczna. [...] W tym stanie rzeczy poruczono artystom plastykom opracowywanie tematów sportowych i wezwano ich do udziału w olimpijskich igrzyskach. [...] Plastycy chętnie skorzystali z otwierającej się skarbnicy nowych motywów. Często jednak stały się one dla nich tylko pretekstem do rozwinięcia raz jeszcze zagadnień swej artystycznej specjalności, w której tkwią, świata poza nią nie widząc. I zdaje się, że nie dojdziemy do wydobycia ducha sportowego w plastyce tak długo, dopóki nie stworzymy warunków, w których te dwie dziedziny wzajemnie się przenikną. Do tego celu konieczne jest głębsze związanie artysty z istotą danego tematu, a nie poprzestawanie na wychwytywaniu samych tylko powierzchownych i anegdotycznych uroków tego motywu” (J. Starzyński, Uwagi o temacie w plastyce. Sport w sætuce, „Arkady” 1936, nr 5, s. 244). 
stów nieznających od strony praktycznej specyfiki dyscyplin sportowych, graficzką o doskonałych „kwalifikacjach” do artystycznego ujęcia szermierki była Wiktoria Goryńska, w pełni realizująca ideę nakreślona przez Nelę Samotyhową: „W grafice dokonywanie się psychicznego stopu między artystą a planszą jest bardzo istotne i głębokie. Aby się mogła stąd narodzić prawda - wszystko musi być tu szczere i rzetelne: i ujęcie tematu - i kompozycja - i technika" ${ }^{45}$. Toteż grafiki Goryńskiej (ale także Rużyckiej, Konarskiej, Telakowskiej i niewspomnianej wcześniej Leonii Nadelmanówny ${ }^{46}$ ) były najczęściej wyróżniane przez krytyków.

W niełatwej tematyce sportu, wyborze i interpretacji tylu różnorodnych dyscyplin graficzki sprawdziły się, proponując interesujące koncepcje formalno-warsztatowe, zwracając uwagę na mniej oczywiste aspekty sportu czy płynące z jego uprawiania korzyści. Prace wymienionych tu graficzek, tak odległe, tak różne od siebie, prezentując niepoślednie walory artystyczne, sa jednocześnie świadectwem odważnego graficznego myślenia i podążania zgodnie $\mathrm{z}$ własna, indywidualną wizją.

\section{Summary}

\section{Sport themes in the graphic art of Polish female artists of the interwar period}

The subject of sport in graphic art was taken by mostly by female Varsowian artists. Among those, the most innovative were the woodcuts by the members of Ryt group, Wiktoria Goryńska, Janina Konarska and Maria Rużycka-Gabryel. All these artists had great passion for sport; Goryńska, who created many works unique for the interwar period, depicted fencing exercises and tournaments as well as the portraits of fencers (Szermierka [Fencing], Ciniczacy szermierze [Practicing fencers] or Autoportret-florecistka [Self-portrait - female foilist]) was a competitive fencer herself; Rużycka-Gabryel took part in competitive watersports and skiing (Narciarz. - rjazd [A Skier], Smarowanie nart [Ski waxing], Sporty wodne [Water sports]). Konarska made a sport series of images in color woodcut (Pitka nożna [Football], Tenis [Tennis], Regaty [Regatta]) as well as several woodcuts on skiing. Among

\footnotetext{
45 N. Samotyhowa, Temat w sqtuce, „Epoka”, 1933, nr 43 z 22 X, s. 7.

46 Jej akwaforta Kolarze w konkursie z 1932 r. na dzieło graficzne o temacie sportowym uzyskała jedną z pięciu równorzędnych nagród.
} 
Wanda Telakowska's visual oeuvre's characteristic features was combining water sports (rowing, sailing) and picturesque landscapes. Female graphic artists connected with Fresk group (Zofia Sznuk-Koskowska, Maja Wolska-Berezowska) created works of distinct style in etching with aquatint. Their works constituted the essence of the Art Deco style. In geometrized and rhythmical forms Koskowska depicted males and children practicing winter sports and tennis, and Wolska presented tennis and rowing in bucolic landscape. The artists presented other sports as well, e.g. volleyball, rugby, boxing or depicted sports practiced just for pleasure and relaxation. Further, graphic artists competed for Poland during art competitions at the Olympic Games. 


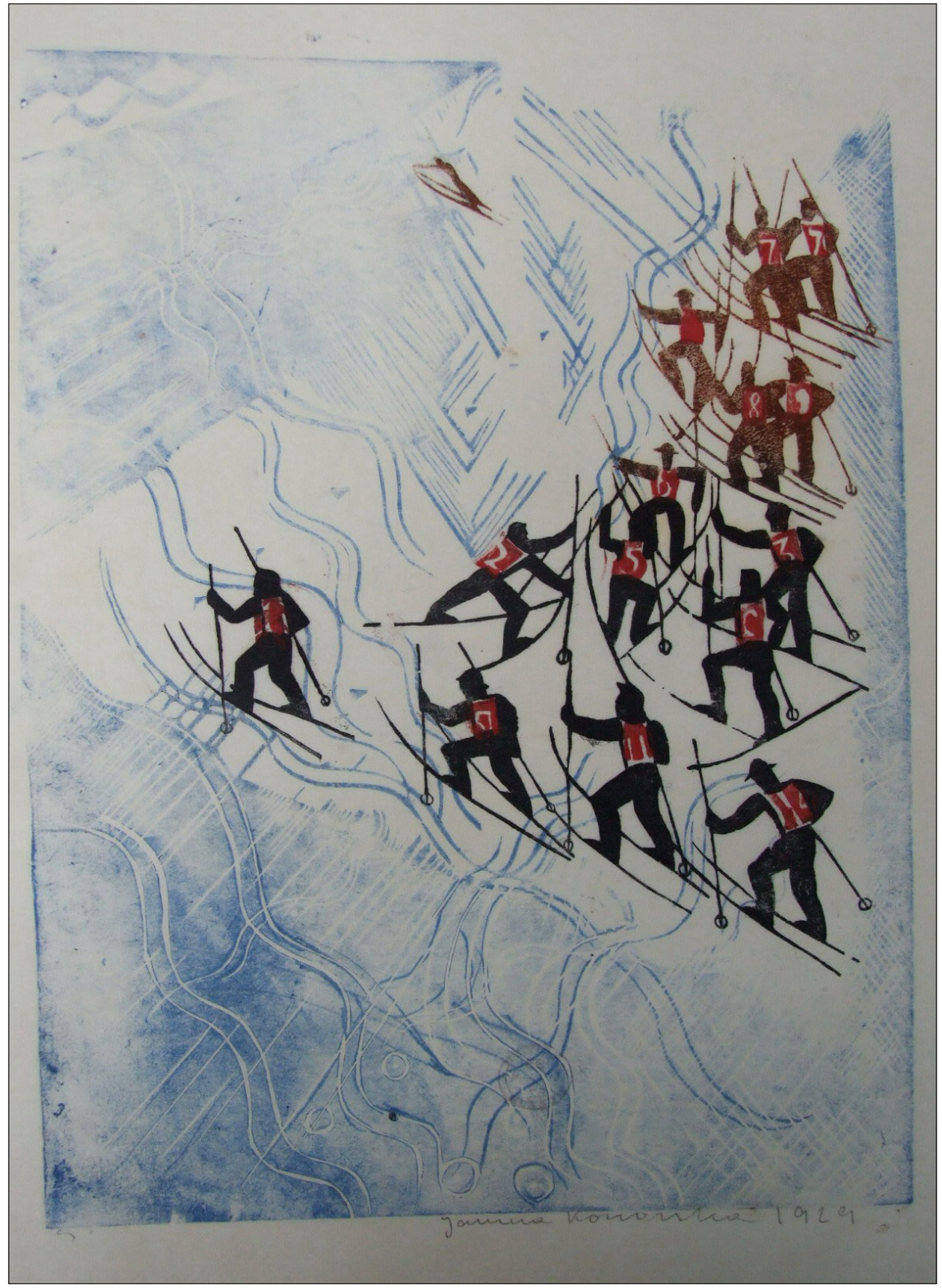

Il. 1. Janina Konarska, Narciarze, 1929, drzeworyt barwny, zb. prywatne, fot. K. Kulpińska 


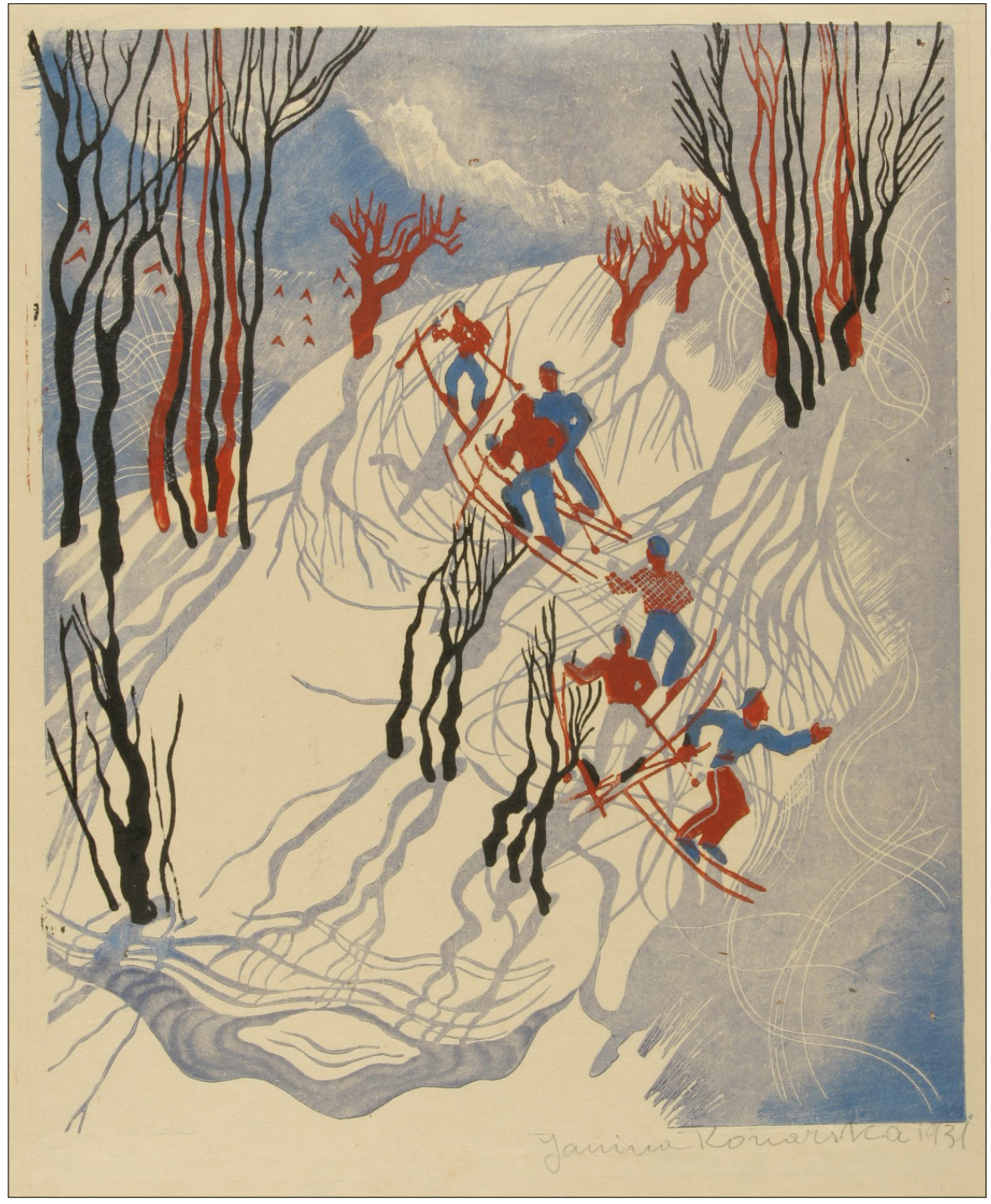

Il. 2. Konarska Janina, Narty, 1931, drzeworyt barwny, MNK, baza cyfrowa MNK 


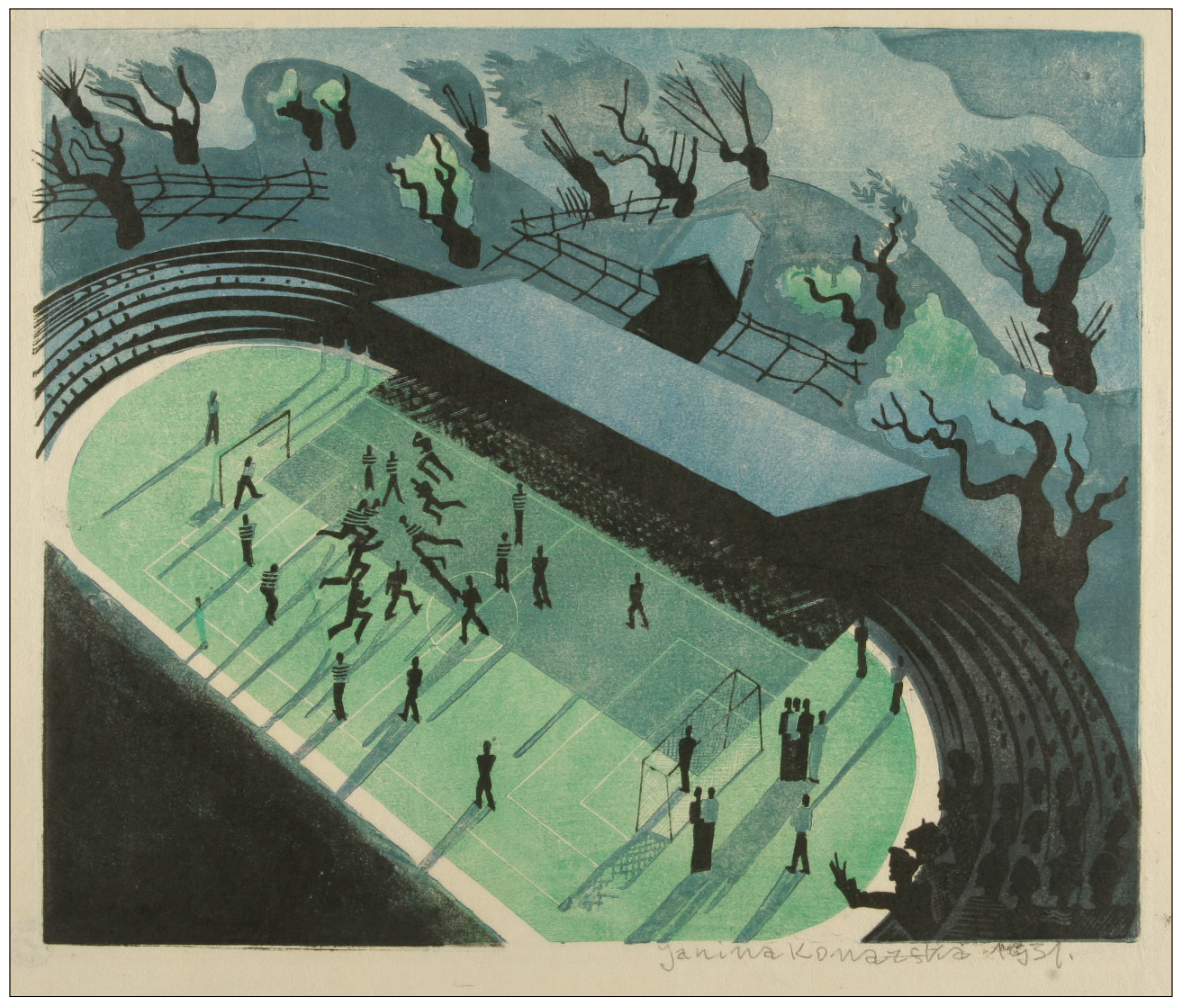

Il. 3. Janina Konarska, Stadion, 1931, drzeworyt barwny, baza cyfrowa MNK 


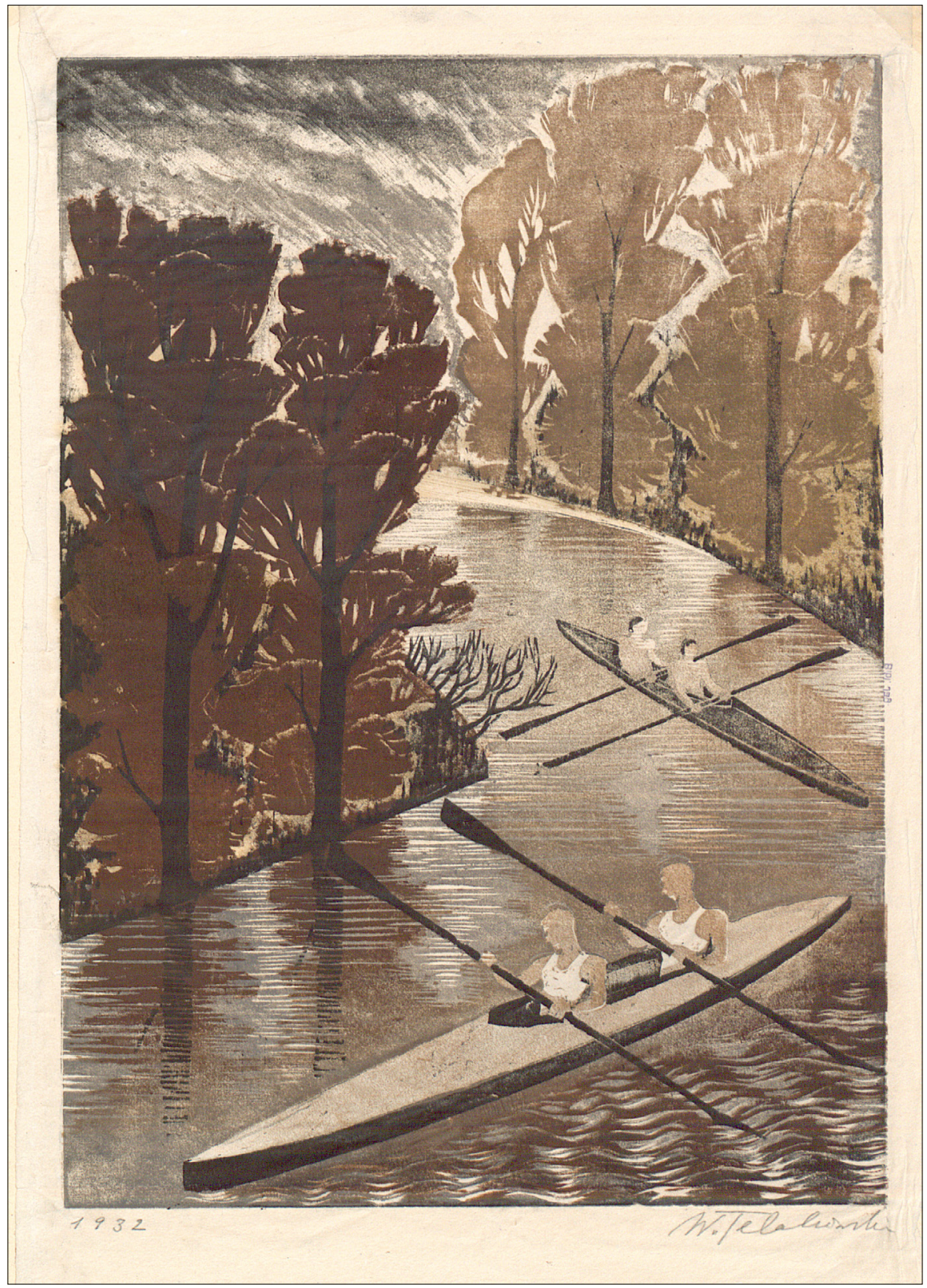

Il. 4. Wanda Telakowska, Sport i prayroda, 1932, drzeworyt, zb. Biblioteki Jagiellońskiej [nazwisko fotografa: do ustalenia] 


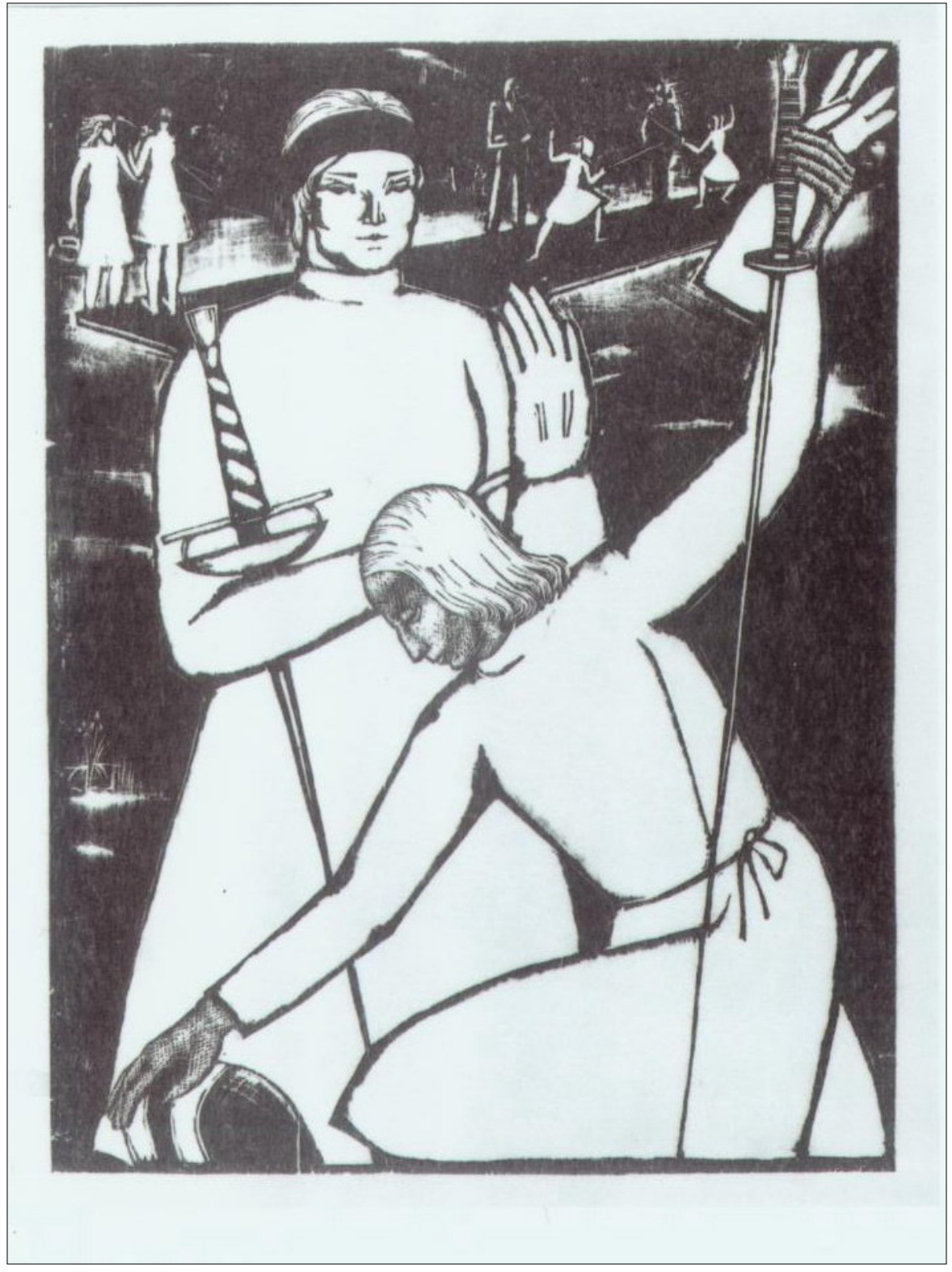

Il. 5. Wiktoria Goryńska, Florecistki wegierskie, 1934, drzeworyt, zb. MNW, fot. T. Żółtowska-Huszcza 
[310]

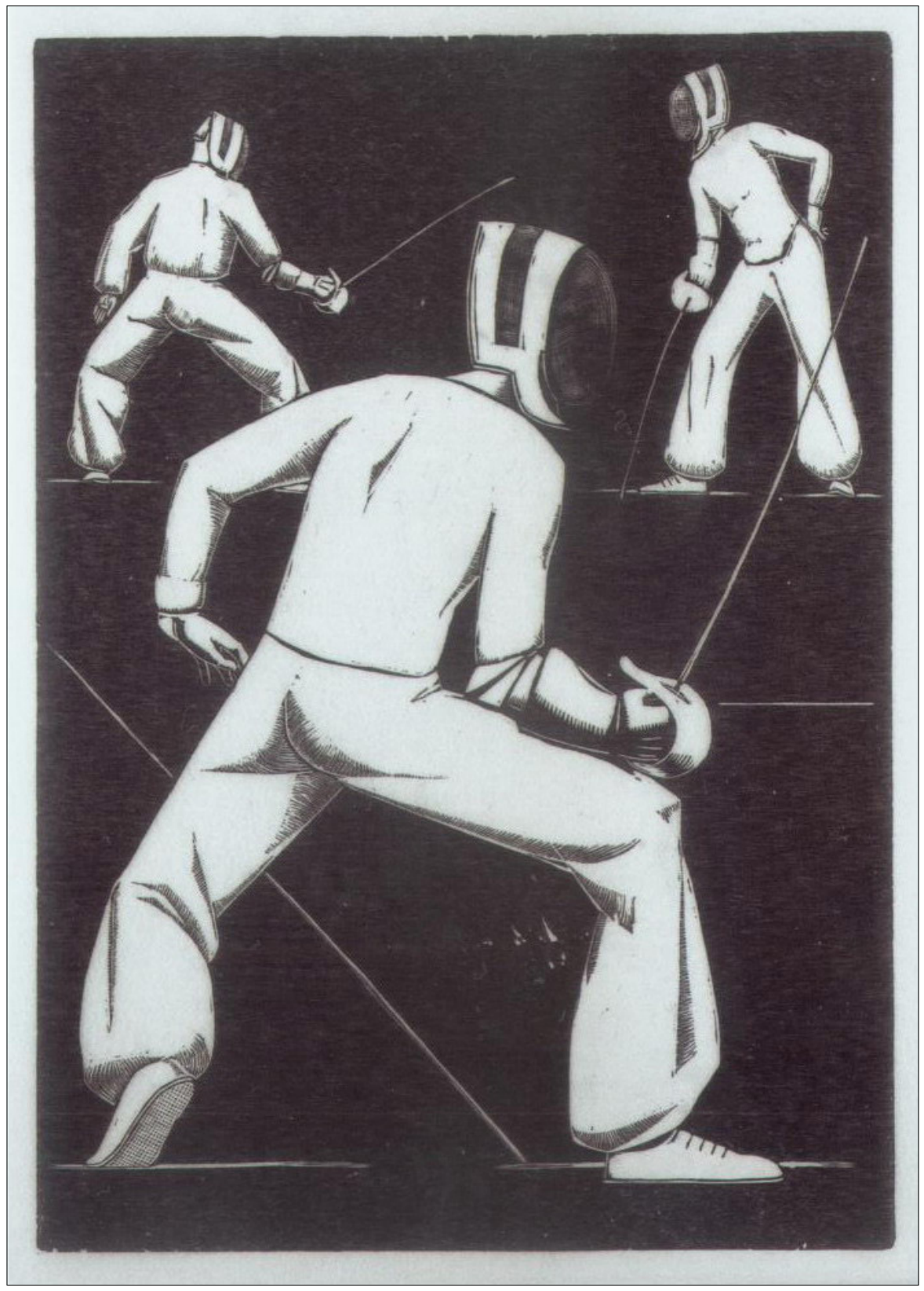

Il. 6. Wiktoria Goryńska, Szermierze, ok. 1932-1935, drzeworyt, zb. MNW, fot. T. Żółtowska-Huszcza 